\title{
Effects of sublethal infection by the parasite Haplosporidium nelsoni (MSX) on gametogenesis, spawning, and sex ratios of oysters in Delaware Bay, USA
}

\author{
Susan E. Ford, Antonio J. Figueras* \\ Shelliish Research Laboratory, Cook College, New Jersey Agricultural Experiment Station, Rutgers University, Port Norris, \\ New Jersey 08349, USA
}

\begin{abstract}
Haplosporidium nelsoni (MSX) is an ascetosporan parasite that has caused heavy mortalities of oysters Crassostrea virginica (Gmelin) on the mid-Atlantic coast of the United States. Oysters in some areas have developed resistance to mortality, which involves an ability to restrict infections and tolerate parasitism for prolonged periods. Effects of such sublethal infections on gametogenesis and spawning were examined in native oysters in Delaware Bay, an estuary where the parasite is enzootic A comparison of infection levels with gonad state in histological sections of 2700 oysters demonstrated a clear inhibition of gametogenesis, in proportion to infection intensity, during late spring when parasite levels were high. Subsequently, however, temperature-associated infection remission occurred; many oysters recovered, developed mature gonads, and spawned before new or recurrent infections proliferated in fall. Inhibition of early gametogenesis was more severe in males than in females. There was no evidence that spawning 'stress' accelerated the development of infections. There was no correlation between year-to-year fluctuation in parasite abundance and oyster setting in Delaware Bay.
\end{abstract}

\section{INTRODUCTION}

Epizootic mortalities of marine bivalves have been reported, over the past $40 \mathrm{yr}$, from many areas in the world (Mackin et al. 1950. Haskin et al. 1965. Andrews 1968, Farley 1975, Alderman 1979, Balouet et al. 1979, Grizel 1983, Elston 1986, Elston et al. 1986). In most cases, the epizootics have been associated with newly recognized pathogens attacking a highly susceptible population. Of great concern have been the large losses to commercial fisheries, in some cases approaching 90 to $95 \%$ of the harvestable population. Far less attention has been paid to sublethal effects of disease, which may also disrupt population structure and diminish the value of the fishery. Particularly important could be effects on reproduction, an obviously critical process in maintaining or replenishing natural stocks.

The potential effects of sublethal disease pressure may increase in relative importance when populations

\footnotetext{
- Present address: Instituto de Investigaciones Marinas, Muelle de Bouzas, s/n, 36208, Vigo, Spain
}

begin to develop resistance to mortality as a result of natural selection. Improved survival, measured against introduced stocks, has been reported in a number of locations for native oysters that have experienced epizootic mortalities (Needler \& Logie 1947, Andrews \& Hewatt 1957, Andrews 1968, Farley 1975, Andrews \& Castagna 1978, Haskin \& Ford 1979, Elston et al. 1987). Although detailed information is presently lacking for most of these cases, the available evidence indicates that hosts become resistant to mortality, but not necessarily to infection (Myhre \& Haskin 1970, Ford \& Haskin 1982, 1987, R. Elston pers. comm., J. D. Andrews pers. comm.).

The development of resistance to mortality has been particularly well documented for oysters Crassostrea virginica (Gmelin), infected by the ascetosporan parasite Haplosporidium nelsoni (MSX) (Haskin et al. 1966, Levine et al. 1980) in Delaware Bay, USA (Haskin \& Ford 1979, Ford \& Haskin 1987). While H, nelsoni continues to infect most oysters in high salinity areas of the Bay, a significant fraction are able to restrict infections to localized, non-lethal infections and to tolerate 
parasite burdens that would kill susceptible oysters (Ford \& Haskin 1987). In fact, parasitized oysters may live for several years, although their condition is generally much poorer than non-parasitized individuals (Ford 1985).

Except for investigations into parasitic castration by trematode parasites (reviewed by Lauckner 1983), there is almost no published information on the effects of parasitism on reproduction of bivalve molluscs. Farley (1968) described destruction of gonad tissue in oysters infected with Haplosporidium nelsoni, but also noted that infected individuals in a surviving population often had gonad development. As part of a larger study of sublethal metabolic effects of $H$. nelsoni parasitism on oysters, we have analyzed reproductive development in oysters exposed to heavy infection pressure in lower Delaware Bay. We were particularly interested in oysters parasitized during the months preceeding and during gametogenesis, when nutrients are accumulated, stored, and converted into gametes (Galtsoff 1964, Eble 1969). Our objectives were to determine (1) whether and to what extent $H$. nelsoni affects gametogenesis and spawning of infected oysters; (2) whether $H$. nelsoni influences sex ratios, or affects males and females differentially; (3) whether spawning weakens oysters so as to accelerate the development of infections; and (4) whether there is a correlation between annual variation in $H$. nelsoni infections and spawning/setting cycles of oysters in Delaware Bay.

\section{METHODS}

Oysters sampled. Oysters Crassostrea virginica were collected in lower Delaware Bay, USA, between 1980 and 1985 as a part of a program to define levels of Haplosporidium nelsoni in native stocks (Ford \& Haskin 1982). Collections used in the present study were made at 4 periods during the reproductive and postreproductive season: late May/early June, late July, late August, and late September (Table 1). These collection dates were designed to measure parasite levels at the onset and early development of infections (July through September) and at the culmination of the annual infection cycle (late May) (Andrews 1966. Ford \& Haskin 1982). Collection dates were almost the same, and temperatures varied by only a few degrees, from year to year (Table 1).

In Delaware Bay, most oysters infected with Haplosporidium nelsoni are found in the high salinity 20 to $26 \mathrm{ppt}$ ) regions of the lower estuary (Fig. 1). This is the



Fig. 1. Oyster seed beds and planting grounds in Delaware Bay, USA

Table 1. Collection dates and bottom water temperature $\left({ }^{\circ} \mathrm{C}\right)$ for $1980-1985$ lower Delaware Bay samples

\begin{tabular}{|c|c|c|c|c|c|c|}
\hline & 1980 & 1981 & 1982 & 1983 & 1984 & 1985 \\
\hline \multicolumn{7}{|c|}{ Late May/Early June } \\
\hline Dates & 23 May & - & 31 May-9 Jun & 6-13 Jun & 6 Jun & 28-29 May \\
\hline Temperature & $18-19$ & & $20-21$ & $20-22$ & $18-21$ & $19-20$ \\
\hline \multicolumn{7}{|l|}{ Late July } \\
\hline Dates & $28 \mathrm{Jul}$ & $30 \mathrm{Jul}$ & 27-29 Jul & 25-27 Jul & $26 \mathrm{Jul}$ & - \\
\hline Temperature & $26-27$ & $25-26$ & $26-28$ & $25-26$ & 24 & \\
\hline \multicolumn{7}{|l|}{ Late August } \\
\hline Dates & - & 27 August & - & 26-29 Aug & 24 Aug & - \\
\hline Temperature & & $22-24$ & & $25-26$ & 24 & \\
\hline \multicolumn{7}{|l|}{ Late September } \\
\hline Dates & 24 Sep & 21-25 Sep & 24-29 Sep & $28 \mathrm{Sep}$ & 24 Sep-4 Oct & - \\
\hline Temperature & 19 & $19-21$ & $19-20$ & 20 & $17-21$ & \\
\hline
\end{tabular}


location of the 'planting grounds' where seed oysters are placed each year for growth and conditioning before market. Seed oyster beds are located in relatively low salinity ( 9 to $18 \mathrm{ppt}$ ) water where $H$. nelsoni is inhibited (Andrews 1964, Haskin \& Ford 1982). Thus, seed oysters have relatively few and light infections when they are transplanted to the lower Bay in May and June at the beginning of the summer infective period (Haskin \& Ford 1982). Samples were therefore divided into 2 groups: (1) oysters that had survived 1 to 2 yr of exposure to $H$. nelsonj in the lower bay; and (2) newly transplanted seed oysters undergoing their first exposure to heavy infection pressure.

In addition to the recent collections, an archived series of slides was examined from a group of James River, Virginia, USA, seed oysters planted in lower Delaware Bay in spring 1964. They were sampled monthly for a period of $5 \mathrm{yr}$, from June 1964 through June 1969. The relatively closely spaced samples in this collection provide a better comparison of temporal infection and reproduction cycles than do the more widely spaced recent samples. Further, they demonstrate the effect of long-term chronic parasitism on reproduction.

Rating of gonad development. Oysters were fixed in Davidson's solution, sectioned through the gill and visceral mass just below the palps, and processed for histological examination according to Ford \& Haskin (1982). Each oyster was assigned to one of 5 gonad developmental stages (Loosanoff 1942). To facilitate comparison of gametogenic and infection cycles in the James River series, a 'Gonad Index' (GI) was estimated by assigning numerical values to developmental categories and calculating a mean for each sample.

Undifferentiated: gonad follicles small and widely scattered just beneath the mantle, sex not clear (GI $=1$ ).

Early development: follicles beginning to expand, primary and secondary gametocytes present (GI $=2$ ).

Late development: follicles greatly expanded and coalesced, although substantial connective tissue remaining between them; gametocytes and mature gametes present $(\mathrm{Gl}=3)$.

Mature: follicles packed with mature gametes have replaced nearly all connective tissue between mantle and digestive gland (GI $=4$ if gonad $\leq 25 \%$ of diameter of visceral mass and 5 if $>25 \%$ ).

Spawned: includes partially and completely spawned individuals; follicles and gonaducts distended, but number of gametes reduced. Gametocytes and mature gametes may remain indicating potential for further spawning. Hemocyte infiltration of gonad may occur in completely spawned oysters (GI $=0$ ).

Rating of Haplosporidium nelsoni levels. Each oyster was rated according to parasite numbers and degree of proliferation (Ford \& Haskin 1982), A 'Weighted Incidence' was determined for the James River series by scoring each oyster according to infection intensity and calculating a mean for each sample. Scores ranged from zero for a patently uninfected individual to 15 for one with a heavy, systemic infection.

None: no patent infection (parasites not detected, but a subpatent infection could exist) (Intensity $=0$ ).

Gill: parasites confined to the gill, usually epithelial or localized subepithelial lesions (Intensity $=1$ to 4 ).

Light Systemic: rare to light systemic infections (Intensity $=4$ to 9).

Advanced Systemic: moderate to heavy systemic infections (Intensity $=10$ to 15 ).

Statistics. Histological sections from 2700 oysters in 136 samples (usually 20 oysters per sample) were examined. Data from the 1980-1985 collections were pooled, according to collection period, into 2 groups: oysters that had been exposed to heavy infection pressure for 1 yr or more and newly transplanted oysters undergoing initial exposure. Differences in gonad development between the 2 groups, between males and females, and between oysters with different infection levels were subjected to ' $G$ ' tests for independence (Sokal \& Rohlf 1981).

Comparison of Haplosporidium nelsoni levels with oyster setting in Delaware Bay. A mean H. nelsoni prevalence was calculated for each year between 1961 and 1984 using data from representative stations in the lower Bay (Ford \& Haskin 1982). Prevalences were arcsine-transformed to place them in a normal distribution (Sokal \& Rohlf 1981). Spawning and setting success for each year was estimated by computing a mean cumulative spat shell ${ }^{-1}$ season $^{-1}$, as measured on test shells suspended and changed at 1 to $2 \mathrm{wk}$ intervals between June and October at 30 to 35 stations throughout the Bay (D. Kunkle pers. comm.). Setting on test shells is significantly correlated with both larval abundance and actual set on the bay bottom (Kunkle \& Ford unpubl.). Correlation analysis was then performed between spat set and arcsine-transformed $H$. nelsoni prevalences in the same and in the preceeding year.

\section{RESULTS}

\section{Histopathology}

There were 2 general pathological conditions of the gonad associated with parasitism. The first involved arrested gametogenesis that occurred in early development and was found mostly in late May samples. The most extreme cases occurred in oysters with advanced infections, in which follicles were small or non-existent (Fig. 2). Frequently, the germinal epithelium was 

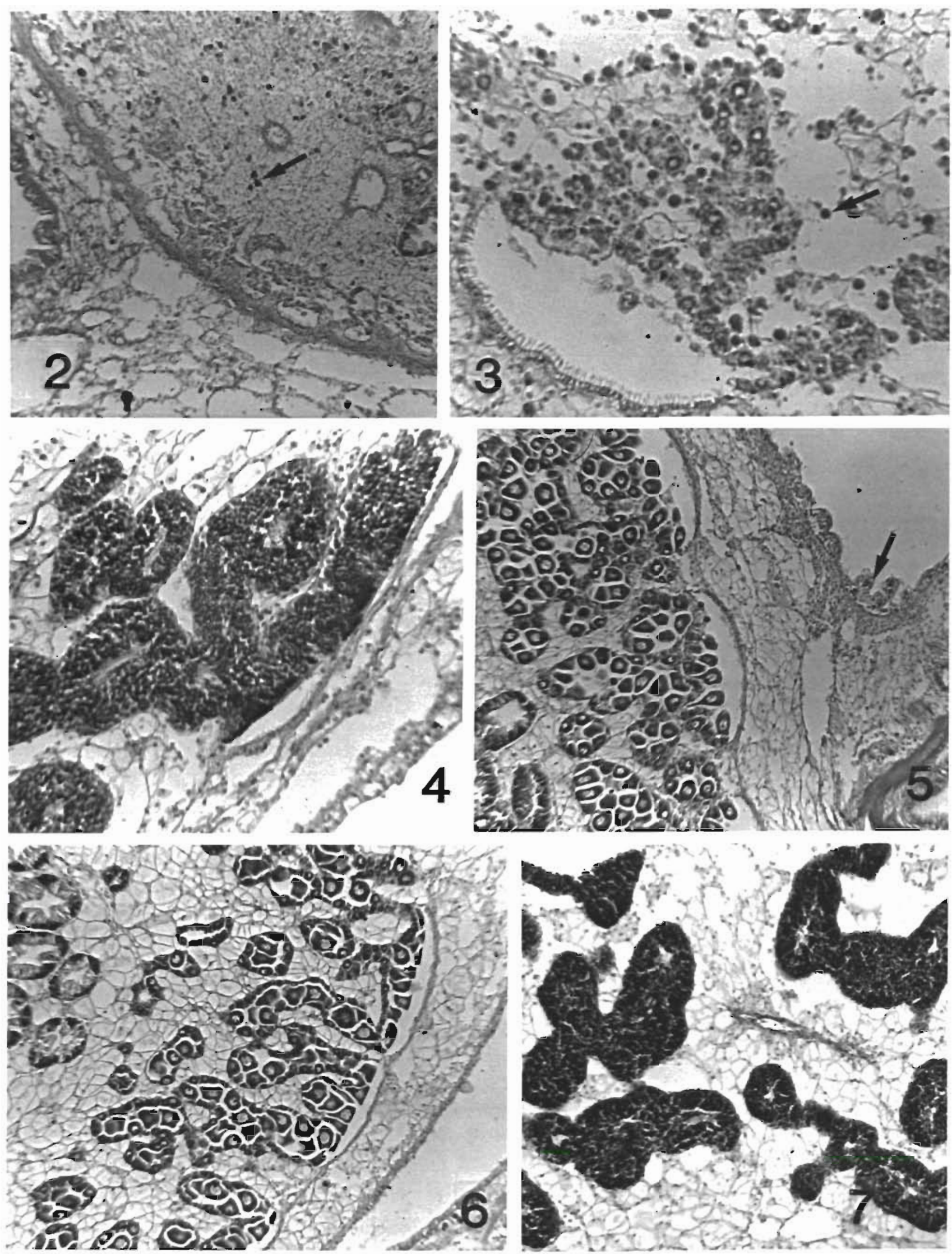
entirely lacking, and when present, cells were sexually undifferentiated. Parasites and hemocytes were abundant in the gonad (as they were in other tissues) and there was a general destruction of tissues throughout the oyster.

Severe, but not complete, inhibition occurred in other systemically infected oysters. In these, gametocytes lined the follicles, but development was asynchronous and retarded compared to uninfected individuals, and many cells appeared to be undergoing autolysis (Fig. 3). In many systemically infected oysters, and in most individuals with gill infections, there were no obvious pathological conditions in the gonad; gametes appeared normal, but they were somewhat less abundant and well developed (Figs. 4 and 5) than those in uninfected oysters (Figs. 6 and 7).

In late July and late August, infected oysters were found with mature or spawned gonads. In most cases, gonads in individuals with light-systemic or gill infections could not be distinguished from those without infections (Fig. 8). Some oysters with advanced infections also showed relatively little pathological damage to the gonad (Fig. 9); parasites were scattered in all tissues, but gametes appeared normal and evidence of spawning was the same as in uninfected oysters. In other advanced cases, tissue disruption was extensive, yet the oysters appeared to have spawned (Fig. 10).

The second pathological condition occurred in welldeveloped gonads, and was generally found in July and August collections. These cases involved complete, but localized, destruction of sex products (Figs. 11 and 12). A similar case was reported by Farley (1968). Parasites were present, along with mature gametes in various stages of degradation, in the lumina of follicles and gonoducts. No parasites were evident in connective tissue between follicles or in other parts of the visceral mass, suggesting that invasion of the gonad had been through the gonoducts. Hemocytes were extremely abundant at the infection site and there was sharp gradation between unaffected and totally destroyed gonad. The area involved usually represented a relatively small portion of the entire gonad and the rest of the tissue appeared normal. This was an extremely rare type of lesion with a frequency of less than $1 \%$ among all oysters examined.

Another rare, but interesting, condition involved an apparently normal, well-developed gonad in juxtaposition to extremely heavy parasite concentrations, accompanied by intense hemocyte aggregations and tissue destruction, in the digestive diverticula (Fig. 13). This type of lesion is characteristic of chronic infections, in which recurrent outbreaks of parasites often develop from digestive epithelia (Farley 1968), usually in late summer and fall, after the reproductive season (Ford 1985).

\section{Infection level vs gonad stage, Delaware Bay natives $1980-1985$}

There were no significant differences $(p>0.05)$ between males and females in frequency distribution among gonad stages for oysters in the same infection category. Therefore, data were combined for both sexes in the same gonad stage and infection category.

\section{Late May}

Approximately $60 \%$ of the oysters collected in late May from the planted grounds, where they had been exposed to Haplosporidium nelsoni for at least $1 \mathrm{yr}$, had patent infections. Of these, $10 \%$ had advanced infections and the remaining $50 \%$ was approximately evenly divided between gill and light systemic infections. Parasitism was clearly associated with retarded gonad development, a condition that became more severe with increasing infection intensity (Fig. 14A). Among oysters with no patent infections, $13 \%$ were undifferentiated, $52 \%$ had developing gonads, and $36 \%$ were classified as mature. In contrast, $75 \%$ of the individuals with advanced infections had undifferentiated gonads, $22 \%$ were developing, and only $3 \%$ were mature. Water temperature during this collection period averaged about $20^{\circ} \mathrm{C}$ (Table 1 ).

Although gonad development in oysters with gill infections appeared somewhat retarded compared to those without patent infections, the differences were not statistically significant. Other comparisons between infection levels, however, were significantly different (Table 2).

\section{Late July}

Collections made in late July, late August, and late September included groups that had been recently (May and June) transplanted from the seed beds to the

Figs. 2 to 7. Crassostrea virginica. Sections of oysters collected in late May. Fig. 2. Section through a heavily parasitized oyster showing complete gonad destruction. Arrow points to a parasite $(100 \times)$. Fig. 3. Infected female oyster showing severe, but not total inhibition of gametogenesis. Arrow points to a parasite $(250 \times)$. Fig. 4. Apparently normal gonad development in a systemically infected male oyster $(100 \times)$. Fig. 5. Apparently normal gonad development in a female oyster with a gill infection. Arrow marks location of parasites in gill epithelium $(100 \times)$. Fig. 6. Developing gonad of an uninfected female oyster (100x). Fig. 7. Developing gonad of an uninfected male oyster $(100 \times)$ 


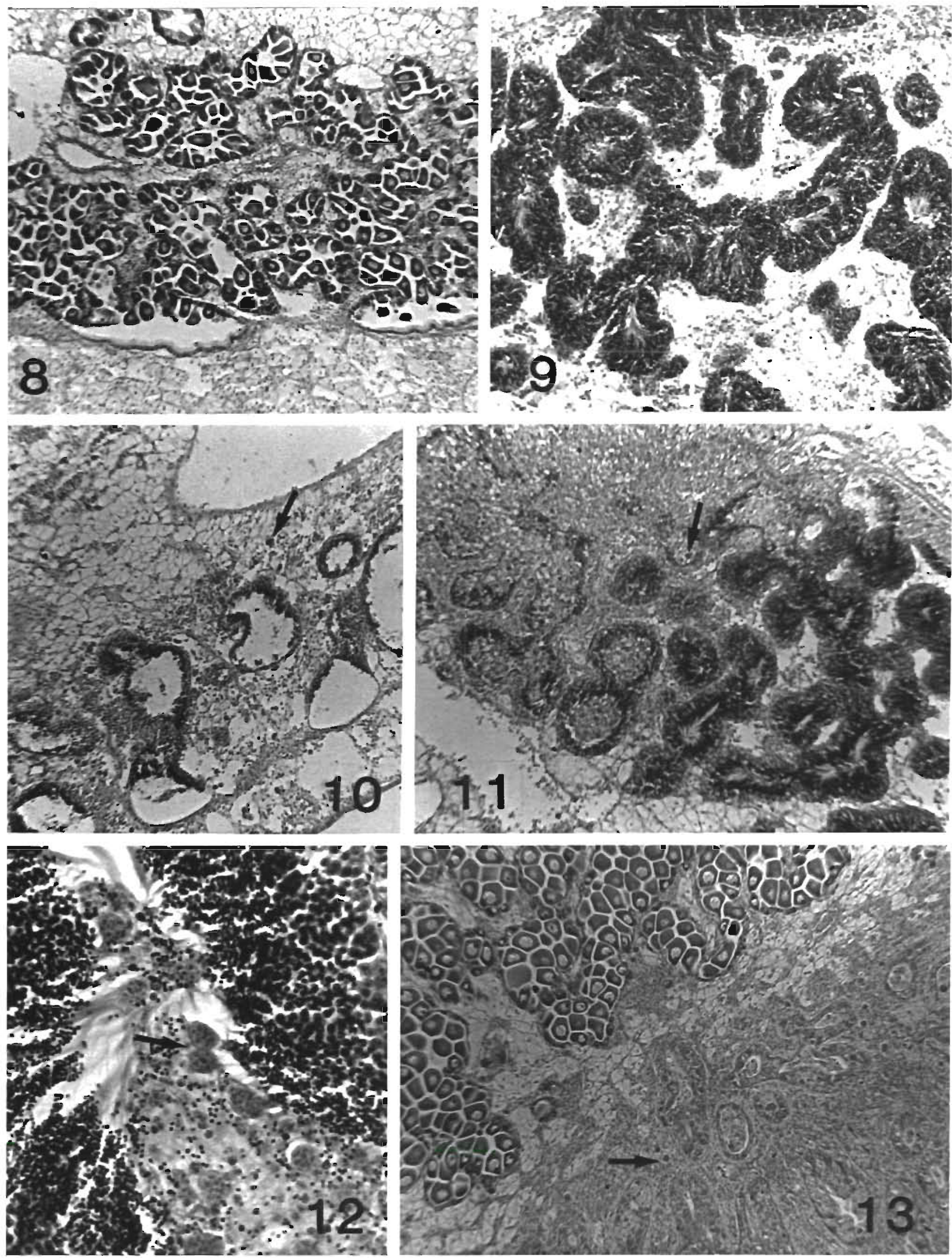


Fig. 14. Crassostrea virginica. Distribution of oysters according to gonad stage and Haplosporidium nelsoni infection level at 4 dates during the reproductive season. Oysters were collected between 1980 and 1985 from the planting grounds of Delaware Bay. Number of oysters in each infection category is shown above bars

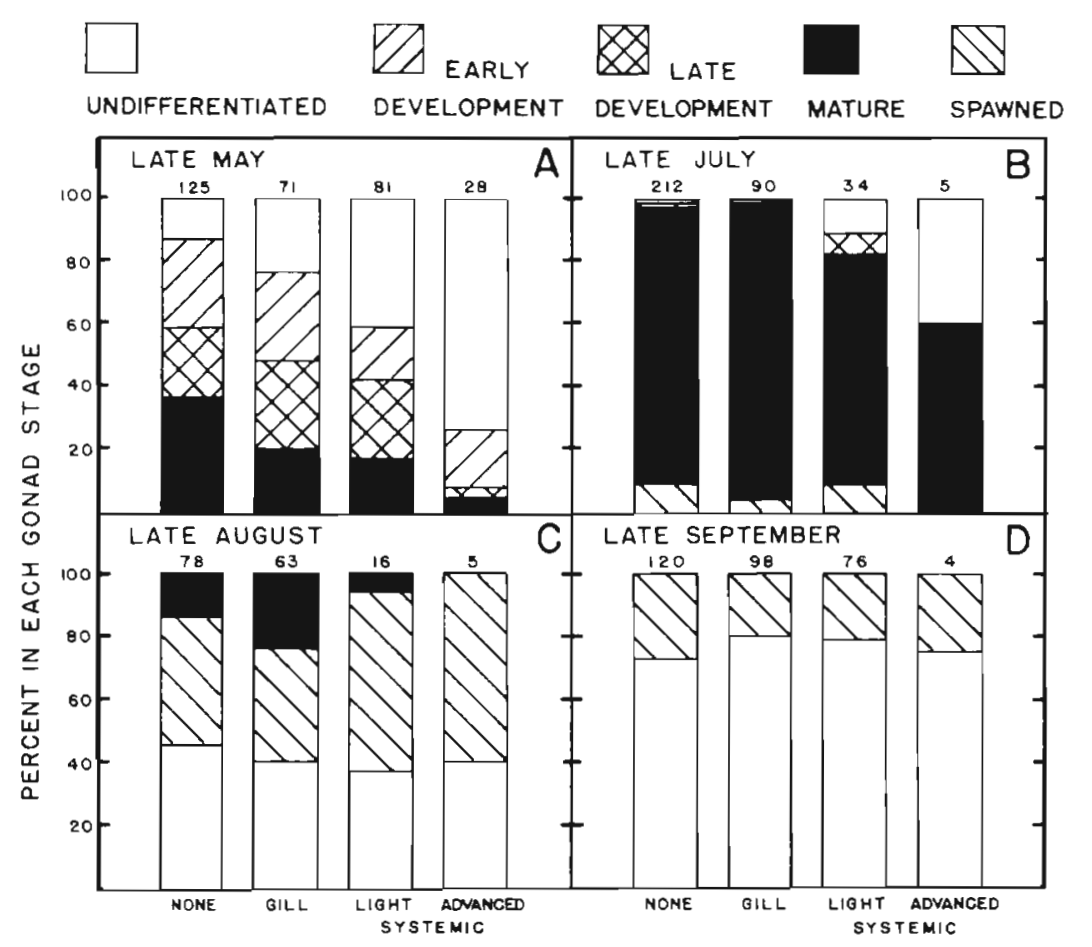

lower bay as well as those that had been in the lower bay for a year or more. Despite different exposure histories, no significant differences $(p>0.05)$ were found in gonad development between the 2 groups at any sampling period. Therefore, data for both were pooled for further analysis.

In late July, Bay temperatures averaged 25 to $27^{\circ} \mathrm{C}$. Haplosporidium nelsoni levels were lower than in late May; most oysters in all infection categories had mature gonads and a few had spawned (Fig. 14B). Only 5 of 341 oysters had advanced infections, but gonad development in 3 of these was classified as mature. Twelve \% of oysters with light systemic infections and 2 of 5 individuals with advanced infections remained undifferentiated. As in late May, there were no significant differences between patently uninfected oysters and those with gill infections, but both were significantly different from pooled systemically infected oysters (Table 2).

\section{Late August}

At the end of August, half the oysters were parasitized, but only $13 \%$ had systemic infections. Water temperatures remained above $25^{\circ} \mathrm{C}$. Most oysters showed evidence of having spawned, including those with systemic infections, and many had returned to the undifferentiated state (Fig. 14C). The distribution of reproductive stages was statistically the same for all infection categories (Table 2)

\section{Late September}

Temperatures averaged somewhat less than $20^{\circ} \mathrm{C}$ in late September, and parasite levels increased in the typical pattern. Sixty $\%$ of the oysters had patent Haplosporidium nelsoni and $27 \%$ had systemic infections. Gonads in most of the oysters had returned to the undifferentiated state, although some of those in systemically infected oysters may never have developed (Fig. 14D). No significant differences in gonad stage were associated with infection category (Table 2).

\section{James River imports, 1964-1969}

The weighted incidence of Haplosporidium nelsoni in James River transplants over $5 \mathrm{yr}$ of sampling

Figs. 8 to 13. Crassostrea virginica. Sections of oysters collected in July and August. Fig. 8. Partially spawned female oyster with a light, systemic infection $(100 \times)$. Fig. 9. Mature gonad in a heavily infected male oyster $(100 \times)$. Fig. 10. Heavily infected male oyster with a spawned gonad. Arrow points to a parasite $(100 \times)$. Fig. 11. Localized invasion and destruction of mature male gonad by invading parasites and host hemocytes. Arrow points to a parasite $(100 \times)$. Fig. 12. Parasites in lumen of male follicle. Same oyster as Fig. 11. Arrow points to a parasite $(1000 \times)$. Fig. 13. Massive lesion of digestive diverticula involving parasites and hemocytes, in juxtaposition to a well-developed female gonad. Arrow points to a parasite $(100 \times)$ 
Table 2. Crassostrea virginica. Contingency table tests for independence ( $G$ statistic) between gonad stage and Haplosporidium nelsoni infection level

\begin{tabular}{|c|c|c|c|c|}
\hline Month & $\begin{array}{l}\text { Infection level } \\
\text { comparison. }\end{array}$ & Number & $G$ & $p$ \\
\hline \multirow[t]{6}{*}{$\begin{array}{c}\text { May } \\
(\mathrm{df}=4)\end{array}$} & $N$ vs $G$ & 196 & 7.49 & $N S^{b}$ \\
\hline & $N$ vs LS & 206 & 25.98 & $<0.01$ \\
\hline & $N$ vs AS & 153 & 47.41 & $<0.01$ \\
\hline & G vs LS & 152 & 6.67 & NS \\
\hline & G VS AS & 99 & 23.89 & $<0.01$ \\
\hline & LS vs AS & 109 & 12.37 & $<0.01$ \\
\hline \multirow{3}{*}{$\begin{array}{c}\text { July } \\
(\mathrm{df}=4)\end{array}$} & & & & \\
\hline & $\begin{array}{l}N \text { vs } G \\
N \text { vs LS \& AS }\end{array}$ & $\begin{array}{l}302 \\
236\end{array}$ & $\begin{array}{r}3.34 \\
15.97\end{array}$ & $\begin{aligned} & N S \\
&<0.01\end{aligned}$ \\
\hline & G vs LS \& AS & 129 & $\hat{1} \overline{3} . \overline{6} 6$ & $<0.0 \mathrm{i}$ \\
\hline \multirow[t]{3}{*}{$\begin{array}{l}\text { August } \\
(\mathrm{df}=3)\end{array}$} & $N$ vs $G$ & 119 & 0.56 & NS \\
\hline & $N$ vS LS \& AS & 85 & 2.02 & NS \\
\hline & G vs LS \& AS & 74 & 3.17 & NS \\
\hline \multirow{4}{*}{$\begin{array}{l}\text { September } \\
(\mathrm{df}=3)\end{array}$} & & & & \\
\hline & $N$ vs $G$ & 219 & 2.36 & NS \\
\hline & $N$ vs LS \& AS & 200 & 2.86 & NS \\
\hline & G vs LS \& AS & 177 & 2.02 & NS \\
\hline \multicolumn{5}{|c|}{$\begin{array}{l}{ }^{\text {a }} \text { : no patent infection; G: gill infections; LS: light systemic } \\
\text { infections; AS: advanced systemic infections } \\
\text { bS: not significant }\end{array}$} \\
\hline
\end{tabular}

demonstrated the characteristic annual infection cycle in Delaware Bay with peaks in winter and late May (Ford \& Haskin 1982). In each year, a sharp decrease in parasite levels followed the May peak and coincided with a new infection period (Fig. 15). Each year, the Gonad Index was relatively low (1.5 to 1.7 ) in late May. In fact, gametogenesis progressed very little compared to native Delaware Bay oysters, between early and late May, despite rising water temperature (Fig. 15). We attribute this to differences in the timing of reproduction associated with physiological races of oysters from different geographical regions (Stauber 1950, Loosanoff \& Nomejko 1951, Ford \& Figueras unpubl.). Between late May and early July, coincident with reduced infection prevalence, the Gonad Index rose sharply. It was at its highest at about the same time that infection levels were lowest, and spawning was completed before parasite levels peaked again in fall.

The James River oysters were imported from an area that had experienced viriualiy no selective mortality from Haplosporidium nelsoni (Andrews 1964), therefore, they suffered very heavy losses when first placed in Delaware Bay. After initial exposure, nearly all of the oysters had patent infections (Ford \& Haskin 1982). By May 1965, cumulative mortality was $65 \%$ and approximately $97 \%$ of the oysters had died by May 1969. To determine whether the consistent decrease in parasitism between late May and early July was the result of recovery or of death of infected oysters, mortalities during this interval were compared with infection level changes (Table 3). The decrease in prevalence of systemically infected oysters ranged between 40 and 75 percentage points. At the same time, mortality was 0 to $18 \%$. The greatest mortality (18\% in 1965) could account for less than half of the systemic infection decline in that year, and except in 1965, mortality



Fig. 15. Crassostrea virginica. Weighted incidence of Haplosporidium nelsoni and gonad indices in James River seed oysters transplanted to Delaware Bay in spring 1964 and sampled through mid-1969. Bottom water temperature was taken at the time of collection. $n-20$ for each sample. Arrows mark major infection periods 
Table 3. Crassostrea virginica. Decrease in prevalence of Haplosporidium nelsoni, and mortality between May and July in James River transplants, 1965-1969

\begin{tabular}{|c|c|c|c|c|c|c|c|c|c|c|}
\hline \multirow{3}{*}{ Year } & \multicolumn{9}{|c|}{$\%$ Prevalence of Haplosporidium nelsoni ${ }^{\text {a }}$} & \multirow{3}{*}{$\begin{array}{l}\% \text { Mortality } \\
\text { May to July }\end{array}$} \\
\hline & \multicolumn{3}{|c|}{ Late May } & \multicolumn{3}{|c|}{ July } & \multicolumn{3}{|c|}{ May to July decrease } & \\
\hline & TOT & LS & AS & TOT & LS & AS & LS & AS & LS \& A.S & \\
\hline 1965 & 70 & 35 & 30 & 40 & 5 & 20 & 30 & 10 & 40 & 17 \\
\hline 1966 & 90 & 40 & 35 & 5 & 0 & 0 & 40 & 35 & 75 & 18 \\
\hline 1967 & 75 & 30 & 30 & 25 & 5 & 5 & 30 & 25 & 55 & 8 \\
\hline 1968 & 70 & 35 & 35 & 25 & 10 & 5 & 15 & 30 & 45 & 0 \\
\hline
\end{tabular}

accounted for less than half of the loss of advanced systemic infection.

\section{Spawning and infection}

To examine the possibility that spawning weakened oysters, so that they were more easily infected and more susceptible to developing disease, we compared infection levels in pre- and post-spawning oysters in late July and late August samples from the 1980-1985 collections. The comparison included oysters undergoing first exposure and those that had been exposed for a year or more. If the above notion were true, we would expect to find more infections among spawned than among pre-spawned oysters. Instead, the distribution of infected individuals was the same, regardless of whether or not they had spawned or how long they had been exposed (Table 4).

\section{Parasitism and sex ratios}

Sex ratios were statistically the same, at each sampling, in lower bay and lower seed bed oysters collected between 1980 and 1985 and in James River transplants sampled between 1964 and 1969. Data from all groups were therefore pooled. Also, there were no statistically significant differences in sex ratios among the 3 categories of infected oysters, so these data were pooled for comparison with patently uninfected oysters.

In late May, individuals with undifferentiated gonads were twice as frequent among infected oysters as among uninfected ones (38 vs $19 \%$ ) (Table 5). Among the remaining, sexually differentiated oysters, the ratio of females to males was nearly twice as great in the infected group $(2.9: 1)$ as in the uninfected group (1.6:1), a difference that was statistically significant (Table 5). By late July, when most oysters had mature gonads, as well as later in the season, female-to-male ratios were similar in both infected and uninfected groups, and averaged approximately $1.5: 1$.

Females predominated at all times and the sex ratio was significantly different from $1: 1$ in most cases (Table 5).

\section{Haplosporidium nelsoni fluctuations and oyster setting variability in Delaware Bay}

Year-to-year fluctuation in spat set on test shells was not correlated with Haplosporidium nelsoni levels in either the same $\left(n=28, r^{2}=0.10\right)$ or the previous year ( $\left.n=27, r^{2}=0.001\right)$.

Table 4. Crassostrea virginica. Comparison of the prevalence of Haplosporidium nelsoni infections in pre- and post-spawned oysters. Percentages are based on the total in each infection category. There were no statistically significant differences between infected and uninfected oysters in any category

\begin{tabular}{|c|c|c|c|c|}
\hline & \multicolumn{2}{|c|}{ First exposure } & \multicolumn{2}{|c|}{ Chronic exposure } \\
\hline & Pre-spawned & Post-spawned & Pre-spawned & Post-spawned \\
\hline \multicolumn{5}{|l|}{ Late July } \\
\hline Uninfected & $182(90 \%)$ & $20(10 \%)$ & $124(89 \%)$ & $15(11 \%)$ \\
\hline Infected & $182(95 \%)$ & $7 \quad(5 \%)$ & $43(90 \%)$ & $5(10 \%)$ \\
\hline \multicolumn{5}{|l|}{ Late August } \\
\hline Uninfected & $11(14 \%)$ & $67(86 \%)$ & $10(15 \%)$ & $55(85 \%)$ \\
\hline Infected & $16(19 \%)$ & $68(81 \%)$ & $12(16 \%)$ & $62(84 \%)$ \\
\hline
\end{tabular}


Table 5. Crassostrea virginica. Sex ratios of oysters infected and uninfected with Haplosporidium nelsoni. Sex ratios of infected and uninfected oysters were compared using contingency table analysis for independence ( $G$ statistic). Ratios within each category were tested for Goodness of Fit to a $1: 1$ ratio: ${ }^{*} p<0.05 ; \cdots p<0.01$; NS: not significant

\begin{tabular}{|c|c|c|c|c|c|}
\hline & \multicolumn{3}{|c|}{ Number of oysters } & \multirow{2}{*}{$\begin{array}{l}\text { Ratio } \\
\text { F:M }\end{array}$} & \multirow{2}{*}{$\begin{array}{l}\text { Infected vs } \\
\text { uninfected }\end{array}$} \\
\hline & ? & $\mathrm{F}$ & $M$ & & \\
\hline Late May & & & & & $G=8.78, p<0.01$ \\
\hline Uninfected & 49 & 127 & 82 & $1.55^{\circ}$ & \\
\hline Infected & 130 & 156 & 54 & $2.89^{\cdots}$ & \\
\hline \multicolumn{6}{|l|}{ Late July } \\
\hline Uninfected & 7 & 187 & 125 & $1.50^{\cdots}$ & $G=0.68, \mathrm{NS}$ \\
\hline Infected & 14 & 49 & 40 & $1.23 \mathrm{NS}$ & \\
\hline \multicolumn{6}{|c|}{ August/September } \\
\hline Uninfected & 228 & 76 & 54 & $1.41 \mathrm{NS}$ & $G=0.55, \mathrm{NS}$ \\
\hline Infected & 232 & 80 & 47 & $1.70^{\circ}$ & \\
\hline
\end{tabular}

\section{DISCUSSION}

There was a clear and consistent retardation of gonad development associated with Haplosporidium nelsoni parasitism at all stages of gametogenesis. The most severe inhibition, however, occurred in the early stages of development and coincided with a late spring prevalence peak at the end of the annual infection cycle. Later gonad development and spawning occurred when parasite burdens were at a relatively low point in the cycle; fewer oysters were infected and there was less inhibition associated with parasitism.

Interpretation of these results depends on a knowledge of the infection cycle for Haplosporidium nelsoni (Ford \& Haskin 1982). The infection period in Delaware Bay extends from June through October infections are detectable by late July and intensity increases to a winter peak. Mortalities occur after infections become systemic, but are reduced during the coldest months of the winter. A late May prevalence peak, frequently showing the highest parasite levels of the year, culminates the infection cycle, and is followed by a rapid disappearance of parasites from the hosts. Oysters found to be infected in late spring have thus been. parasitized since the previous summer or early fall, although the level of parasitism during the interim may have been lighter or heavier than that found in the May sample.

Haplosporidium nelsoni infections are associated with a number of biochemical and physiological changes that become progressively more severe with increased infection intensity. They include depressed filtration rates (Newell 1985), enzyme levels (Eble 1966, Mengebier \& Wood 1969), hemolymph protein concentrations (Ford 1986), and stored glycogen levels (Barber et al. 1988). All of these conditions indicate major disruptions of physiological/metabolic processes that would diminish the substrates needed for all energy-demanding functions, including gametogenesis. These data along with the frequently poor condition of systemically infected oysters suggests that lack of gonad development is part of a general host debilitation rather than a specific effect on the gonad.

The lack of mortality sufficient to explain the loss of systematic infections between late May and early July is true of Delaware Bay native oysters as well as the James River imports (Ford \& Haskin 1982). It indicates that many of the oysters with well-developed and spawned gonads late in the summer had recovered from the disease, which presented a clear stress in May. Farley (1968) also reported histological evidence of infection remission in Chesapeake Bay (USA) oysters, although he did not report when it occurred. The recovery is thought to result from a temperature-mediated response or condition in oysters that destroys parasites at or above $20^{\circ} \mathrm{C}$ (Myhre \& Haskin 1970. Ford \& Haskin 1982, Ford 1985). Recovery appeared to be reasonably complete as far as gametogenesis was concerned, since by late July approximately $96 \%$ of the oysters had mature or spawned gonads. Further, there were no significant differences, by late July, between oysters newly transplanted from the seed beds to the lower bay and those that had been under heavy disease pressure for a year or more. Another indication that recovery was an important factor allowing gametogenesis and spawning is that the gonad index of the James River oysters followed essentially the same pattern and reached the same levels during the reproductive season in 4 consecutive years of heavy infection pressure, in which at least $75 \%$ of the oysters (surviving to that time) had patent infections each year. 
The establishment and development of new infections during the summer appeared to have little effect on reproduction of newly exposed oysters. During the reproductive period, new infections are for the most part confined to the gill epithelium, where they may cause severe local damage, but where they rarely cause general symptoms of disease (Ford \& Haskin 1982, Ford 1986).

Under the proper conditions of temperature and food or stored energy reserves, gametogenesis can be very rapid in Crassostrea virginica. Loosanoff \& Davis (1952) reported that the time required for undifferentiated Long Island Sound (USA) oysters to produce ripe gametes was $8 \mathrm{~d}$ at $20^{\circ} \mathrm{C}$ and $5.4 \mathrm{~d}$ at $25^{\circ} \mathrm{C}$. Price \& Maurer (1971) calculated temperature requirements for gamete maturation of Delaware Bay oysters using degree days. Using their figure of 130 degree days (above $12^{\circ} \mathrm{C}$ ) for oysters held in the field with access to natural food and an approximate mean temperature of $23^{\circ} \mathrm{C}$ between late May and mid-July, it would be possible for healthy oysters to go from an undeveloped to a mature state in about $2 \mathrm{wk}$. This capacity, combined with the relatively rapid decrease of parasite prevalence in June, helps to explain the advanced reproductive condition, in late July, of oysters that only 6 to $8 \mathrm{wk}$ before had evidenced severe inhibition of gametogenesis

Mackin (1962) investigated the relationship between infection by another oyster pathogen, Perkinsus (Dermocystidium, Labyrinthomyxa) marinus (Mackin et al. 1950, Levine 1978) and spawning of oysters in Louisiana, USA. It had been noted that heavy mortalities occurred after spawning and Mackin wished to examine the possibility that spawning so weakened oysters that they became more susceptible to infection and disease. After examining histological sections of oysters before and after spawning, he concluded that there was no relationship between disease and spawned condition or even advanced gonad development. He did find, however, that oysters which were heavily infected during the period of early gametogenesis were 'castrated'. Mackin's results are very similar to our own, including the lack of evidence supporting the hypothesis that spawning enhances the probability of infection and disease development.

Two other studies also reported that parasitism delayed, but did not prevent, breeding of bivalves. Williams (1969) found that infestation of mussels Mytilus edulis by the copepod Mytilicola intestinalis delayed reproduction, while Ford (1985) reported delayed gametogenesis and spawning associated with chronic infections of Haplosporidium nelsoni in oysters. In all cases, the parasites were probably interfering with the apportionment of energy to developing gametes, either through competition or by disrupting normal physiological/metabolic processes, thus lengthening the time required to amass the quantity of nutrients needed for gonad maturation. Another possibility, suggested by Williams (1969), is that parasitism interfered with hormonal control of reproduction by disrupting neurosecretory cycles that are closely associated with reproduction in many bivalves (Sastry 1979).

The disproportionately high number of females among infected oysters compared to uninfected individuals in the late May samples has several possible explanations: (1) females are more prone to infection; (2) infected females are less likely to die; or (3) early gametogenesis in females is less inhibited by infection than it is in males. The large number of undifferentiated oysters at this date and the fact that ratios were no longer related to infection later in the summer, when most individuals were differentiated, favors the last explanation and suggests that male gonads developed primarily after infection pressure was reduced.

Crassostrea virginica is capable of changing sex between breeding seasons (reviewed by Galtsoff 1964). The variables found to influence sex have been thoroughly reviewed and discussed by Kennedy (1983). For the interpretation of our results, the most pertinent information comes from studies in which oysters were experimentally injured. Anemiya (1935) and later Egami (1953) (both cited in Kennedy 1983) removed portions of gill and found that injured groups had lower female-to-male ratios than controls. They proposed that interference with feeding increased the tendency toward maleness. Many other reports also indicate that poor food conditions favor the development of males (Kennedy 1983). In another set of experiments, Bahr \& Hillman (1967) and Davis \& Hillman (1971) filed the growing shell edges repeatedly during the fall and spring, forcing oysters to continuously repair shell. When sexes were determined in early summer, there were significantly more males in the shell-damaged groups. These investigators hypothesized that diversion of energy to shell repair had limited the amount available for gametogenesis and resulted in the production of males.

Implied in the above reasoning is that energy requirements for females are greater than those for males, thus conditions that interfere with provision of resources to the gonad should push the sex ratio in favor of males. As noted by Kennedy (1983), however, equal amounts of gametes may require equal amounts of energy, regardless of sex. Our data contradict the hypothesis that stress favors the production of males, since Haplosporidium nelsoni disease is clearly a severe stress, yet at all times and in all infection categories, females outnumbered males. The evidence that disease retarded male development to a greater 
degree than female development is also at variance with this hypothesis. The sex ratios found in Delaware Bay were in the same range as those reported for upper Chesapeake Bay (where H. nelsoni is usually absent) by Kennedy (1983) and indicate that the disease is not associated with a disruption in the balance of sexes that might adversely affect recruitment.

Two important parameters not measured by this study were gamete quality and quantity. Larval viability is diminished when parent stocks are stressed by lack of food (Helm et al. 1973, Gabbott \& Bayne 1975, Bayne et al. 1975, 1978). Also, oysters exposed to low levels of crude oil for several weeks during gametogenesis could not be induced to spawn, even though histologiral examination showed moderate gonad development, compared to controls, which spawned readily (Manger 1976). If Haplosporidium nelsoni parasitism has disturbed gametogenesis and spawning more than the histological evidence indicates, then some of the year-to-year variability in spawning and setting of oysters in areas enzootic for $H$. nelsoni might be caused by fluctuations in parasite abundance (Ford \& Haskin 1982). The lack of correlation between longterm parasite fluctuations and setting cycles in Delaware Bay may indicate that gametes produced by 'recovered' or newly infected oysters are perfectly viable. A more likely explanation, however, is that the majority of broodstock in the Bay is located on the upper Bay seed beds where low salinity protects oysters from significant disease pressure. The effect of sublethal parasitism on the quantity and quality of gametes produced by lower Bay oysters may still be important and is currently being examined at this laboratory

The initial massive mortalities in lower Chesapeake and Delaware Bays in the late 1950 s and early 1960 s undoubtedly reduced set potential (Andrews 1979) in both regions and the continued scarcity of oysters in the high salinity areas probably still diminishes recruitment. Nevertheless, both regions have experienced very good sets in some recent years, indicating the potential for recovery from epizootic mortality in a population of organisms such as oysters, which produce huge numbers of gametes.

Acknowledgements. We thank D. O Connor for preparing and reading slides; D. Kunkle, W Richards, and C. Phillips for sample collection; and $\mathrm{H}$. Haskin for encouragement and support. B. Barber, B. MacDonald, and H. Haskin provided helpful comments on the manuscript. This study was funded by the National Marine Fisheries Service under PL 88-309 (to H. Haskin), by the New Jersey Department of Environmental Protection, and by a fellowship from the Comision Asesora de Investigación Cientiifica y Tecnica de España to A. J. F. This is New Jersey Agricultural Experiment Station Publication No. D 32504-2-87, supported by state funds.

\section{LITERATURE CITED}

Alderman, D. J. (1979). Epizootiology of Marteilia refringens in Europe Mar Fish. Rev. 41.67-69

Andrews, J. D. (1964). Oyster mortality studies in Virginia. V MSX in James River public seed beds. Proc. natl Shellfish. Ass. 53: 65-84

Andrews, J. D. (1966). Oyster mortality studies in Virginia. V. Epizootiology of MSX, a protistan parasite of oysters. Ecology 47: 19-31

Andrews, J. D. (1968). Oyster mortality studies in Virginica. VII. Review of epizootiology and origin of Minchinia nelsoni. Proc. natl Shellfish. Ass. 58: 23-36

Andrews, J. D. (1979). Pelycypoda: Ostreidae. In: Giese, A. C. Pearse, J. S. (eds.) Reproduction of marine invertebrates, Vol 5. Academic Press, New York, p. 293-341

Andrews, J. D., Castagna, M. (1978). Epizootiology of Minchinia costalis in susceptible oysters in seaside bays of Virginia s Eastern Shore, 1959-1976. J. Invertebr Pathol. 32: $124-138$

Andrews, J. D., Hewatt, W. G. (1957). Oyster mortality studies in Virginia. II. The fungus disease caused by Dermocystidium marinum in oysters of Chesapeake Bay. Ecol. Monogr. 27: 1-26

Bahr, L. M., Hillman, R. E. (1967). Effects of repeated shell damage on gametogenesis in the American oyster Crassostrea virginica (Gmelin). Proc. natl Shellfish. Ass. 57: $59-62$

Balouet, G., Chastel, C., Cahour, A., Quillard, A., Poder, M. (1979). Etude epidemiologique et pathologique de la maladie de l'huitre plate en Bretagne. Sci. Pêche 289 : $13-25$

Barber, B. J., Ford, S. E., Haskin, H. H. (1988). Relationships among condition index, glycogen level, reproductive effort, and intensity of MSX (Haplosporidium ne/soni) infection in oysters, Crassostrea virginica (A.bstract). J. Shellfish Res. (in press)

Bayne, B. L., Gabbott, P. A., Widdows, J. (1975). Some effects of stress in the adult on the eggs and larvae of Mytilus edulis L. J. mar. biol. Ass. U. K. 55: 675-689

Bayne, B. L., Holland, D. L., Moore, M. N., Lowe, D. M. Widdows, J. (1978). Further studies on the effects of stress on the adult on eggs of Mytilus edulis. J. mar. biol. Ass. U. K. 58: 825-841

Davis, N. W., Hillman, R. E. (1971). Effect of artificial shell damage on sex determination in oysters (Abstract). Proc natl Shellfish. Ass. 61:2

Eble, A. F. (1966). Some observations on the seasonal distribution of selected enzymes in the American oyster as revealed by enzyme histochemistry. Proc. natl Shell.fish. Ass. 56: $37-43$

Eble, A. F. (1969). A histochemical demonstration of glycogen, glycogen phosphorylase and branching enzyme in the American oyster Proc. natl Shellfish. Ass. 59: 27-34

Elston, R. A. (1986). An intranuclear pathogen [Nuclear Inclusion $X(N[X)]$ associated with massive mortalities of the pacific razor clam, Siliqua patula. J. Invertebr. Pathol 47 : 93-104

Elston, R. A., Farley, C. A., Kent, M. L. (1986). Occurrence and significance of bonamiasis in European flat oysters Ostrea edulis in North America. Dis. aquat. Org. 2: 49-54

Elston, R. A., Kent, M. L., Wilkinson, M. T (1987). Resistance of Ostrea edulis to Bonamia ostrea infection. Aquaculture 64: $237-242$

Farley, C. A. (1968). Minchinia nelsoni (Haplosporida) disease syndrome in the American oyster Crassostrea virginica. J Protozool. 15: 585-599 
Farley, C. A. (1975). Epizootic and enzootic aspects of Minchinia nelsoni (Haplosporida) disease in Maryland oysters. J. Protozool. 22: 418-427

Ford, S. E. (1985). Chronic infections of Haplosporidium nelsoni (MSX) in the oyster (rassostrea virginica. J. Invertebr Pathol. 45: 94-107

Ford, S. E. (1986). Comparison of hemolymph proteins between resistant and susceptible oysters, Crassotrea virginica, exposed to the parasite Haplosporidium nelsoni (MSX). J. Invertebr. Pathol. 47: 283-294

Ford, S. E., Haskin, H. H. (1982). History and epizootiology of Haplosporidium nelsoni (MSX), an oyster pathogen, in Delaware Bay, 1957-1980. J, Invertebr. Pathol. 40: 118-141

Ford, S. E., Haskin, H. H. (1987). Infection and mortality patterns in strains of oysters Crassostrea virginica selected for resistance to the parasite Haplosporidium nelsoni (MSX). J. Parasit. 73: 368-376

Gabbott, P. A., Bayne, B. L. (1975). Biochemical effects of temperature and nutritive stress on Mytilus edulis L. J. mar. biol. Ass. U. K. 53: 269-286

Galtsoff, P. S. (1964). The America Oyster, Crassostrea virginica Gmelin. US Fish Wildl. Serv. Fish. Bull. 64: 1-480

Grizel, H. (1983). Impact de Marteilia refringens et de Bonamia ostreae sur l'ostreiculture Bretonne. Coun. Meet. int. Coun. Explor. Sea C.M.-ICES/Gen: 9, Mini Symp., p. $1-30$

Haskin, H. H., Canzonier, W. J., Myhre, J. L. (1965). The history of MSX on Delaware Bay oyster grounds, 1957-65. Am. Malacol. Union Bull. 32: 20-21

Haskin, H. H., Ford, S. E. (1979). Development of resistance to Minchinia nelsoni (MSX) mortality in laboratory-reared and native oyster stocks in Delaware Bay. Mar. Fish. Rev. 41: $54-63$

Haskin, H. H., Ford, S. E. (1982). Haplosporidium nelsoni (MSX) on Delaware Bay seed oyster beds: a host-parasite relationship along a salinity gradient. J. Invertebr. Pathol. 40: $388-405$

Haskin, H. H., Stauber, L. A., Mackin, J. A. (1966). Minchinia nelsoni n. sp. (Haplosporida, Haplosporidiidae): causative agent of the Delaware Bay oyster epizootic. Science 153: $1414-1416$

Helm, M. M., Holland, D. L., Stephenson, R. R. (1973). The effect of supplementary algal feeding of a hatchery breeding stock of Ostrea edulis L. on larval vigour. J. mar. biol Ass. U. K. 53: 673-684

Kennedy, V S. (1983). Sex ratios in oysters, emphasizing Crassostrea virginica from Chesapeake Bay, Maryland. Veliger 25: 329-339

Lauckner, G. (1983). Diseases of Mollusca: Bivalvia. In: Kinne, O. (ed.) Diseases of marine animals, Vol. II. Biologische Anstalt Helgoland, Hamburg, p. 477-963

Levine, N. D. (1978). Perkinsus gen. n. and other new taxa in the protozoan phylum Apicomplexa. J. Parasitol. 64: 549

Levine, N. D., Corliss, J. O., Cox, F. E. G., Deroux, G., Grain, J. Honigberg, B. M., Leedale, G. F., Loeblich III, A. R.,
Lom, J., Lynn, D., Merinfeld, E. G., Page, F. G., Poljansky, G., Sprague, V., Vavra, J., Wallace, F. G. (1980). A newly revised classification of the Protozoa. J. Protozool. 27. $35-58$

Loosanoff, V L. (1942). Seasonal gonadal changes in the adult oysters, Ostrea virginica, of Long lsland Sound. Biol. Bull. mar biol. Lab., Woods Hole 83: 195-206

Loosanoff, V L., Nomejko, C. A. (1951). Existence of physiologically different races of oysters, Crassostrea virginica. Biol. Bull. mar. biol. Lab., Woods Hole 101: 151-156

Loosanoff, V. L., Davis, H. C. (1952). Temperature requirements for maturation of gonads of northern oysters. Biol. Bull. mar, biol. Lab., Woods Hole, 103: 80-96

Mackin, J. G. (1962). Oyster diseases caused by Dermocystidium marinum and other microorganisms in Louisiana In: Mackin, J. G., Hopkins, S. H. (eds.) Studies on oysters in relation to the oil industry. Publs Inst. mar. Sci. Univ. Tex. 7: 132-299

Mackin, J. G., Owen, H. M., Collier, A. (1950). Preliminary note on the occurrence of a new protistan parasite, Dermocystidium marinum n. sp. in Crassostrea virginica (Gmelin). Science 111: 328-329

Manger, K. A. (1976). Effects of Nigerian crude oil on the survival and reproduction of the American oyster, Crassostrea virginica Gmelin. Masters thesis, Rutgers University, New Brunswick, New Jersey

Mengebier, W. L., Wood, L. (1969). The effects of Minchinia nelsoni infection on enzyme levels in Crassostrea virginica - II. Serum phosphohexose isomerase. Comp. Biochem. Physiol. 29: 265-270

Myhre, J. L., Haskin, H. H. (1970). MSX infections in resistant and susceptible oyster stocks. (Abstract) Proc. natl Shellfish. Ass. 60: 9

Needler, A. W H., Logie, R. R. (1947). Serious mortalitie"s in Prince Edward Island oysters caused by a contagious disease. Trans. R. Soc. Can., Ser. III 41 (V): 73-89

Newell, R. I. E. (1985). Physiological effects of the MSX parasite Haplosporidium nelsoni (Haskin, Stauber, and Mackin) on the American oyster, Crassostrea virginica. J. Shellfish Res. 5: 91-96

Price, K. S., Maurer, D. (1971). Holding and spawning Delaware Bay oysters (Crassostrea virginica) out of season. II. Temperature requirements for maturation of gonads. Proc. natl Shellfish. Ass. 61. 29-34

Sastry, A. N. (1979). Pelecypoda (excluding Ostreidae). In: Giese, A. C., Pearse, J. S. (eds.) Reproduction of marine invertebrates, Vol. 5. Academic Press, New York, p. $113-292$

Sokal, R. R., Rohlf, F. J. (1981), Biometry. W H. Freeman and Co, New York

Stauber, L. A. (1950). The problem of physiological species with special reference to oysters and oyster drills. Ecology 31: 109-118

Williams, C. S. (1969). The effect of Mytilicola intestinalis on the biochemical composition of mussels. J. mar. biol. Ass. U. K. $49: 161-173$ 